\title{
Maternal hypothyroxinaemia in early pregnancy and school performance in 5-year-old offspring
}

\author{
Anna M E Noten', Eva M Loomans ${ }^{2,3}$, Tanja G M Vrijkotte ${ }^{4}$, Peter M van de Ven ${ }^{5}$, \\ A S Paul van Trotsenburg ${ }^{6}$, Joost Rotteveel ${ }^{1}$, Manon van Eijsden ${ }^{2,7}$ and \\ Martijn J J Finken ${ }^{1}$ \\ 'Department of Pediatrics, VU University Medical Center, PO Box 7057, 1007 MB Amsterdam, The Netherlands, \\ ${ }^{2}$ Department of Epidemiology, Documentation and Health Promotion, Public Health Service Amsterdam, \\ Amsterdam, The Netherlands, ${ }^{3}$ Department of Developmental Psychology, Tilburg University, Tilburg, \\ The Netherlands, ${ }^{4}$ Department of Public Health, Academic Medical Center, University of Amsterdam, Amsterdam, \\ The Netherlands, ${ }^{5}$ Department of Epidemiology and Biostatistics, VU University Medical Center, Amsterdam, \\ The Netherlands, ${ }^{6}$ Department of Pediatric Endocrinology, Academic Medical Center, Emma Children's Hospital, \\ University of Amsterdam, Amsterdam, The Netherlands and ${ }^{7}$ Department of Health Sciences, VU University, \\ Amsterdam, The Netherlands
}

\author{
Correspondence \\ should be addressed \\ to $\mathrm{M} J \mathrm{~J}$ Finken \\ Email \\ m.finken@vumc.n
}

\section{Abstract}

Objective: Overt hypothyroidism in pregnant women is associated with a lower intelligence quotient in their children. More recently, subtle decreases in maternal thyroid function have also been associated with neurodevelopmental impairment in offspring. We tested the effect of hypothyroxinaemia during early pregnancy on school performance. Design: This was a longitudinal study that included the data of 1196 mother-child pairs from the Amsterdam Born Children and Their Development study.

Methods: Maternal serum free thyroxine $\left(\mathrm{T}_{4}\right)$ and TSH were obtained at a median gestational age of 12.9 (interquartile range: 11.9-14.3) weeks. School performance was assessed at age 5 years and based on scores obtained in arithmetic and language tests from the national monitoring and evaluation system. Poor school performance was defined as a test result $<25$ th percentile and subnormal school performance as a result $<50$ th percentile of the norm population. To estimate the impact of possible non-response bias, we conducted inverse-probability weighted analyses.

Results: Maternal hypothyroxinaemia (i.e., a maternal free $\mathrm{T}_{4}$ in the lowest $10 \%$ of distribution) was associated with a 1.61 (95\% Cl: 1.05-2.47) -fold increased odds of subnormal arithmetic performance after adjustment for confounders $(P=0.03)$. However, the odds ratio dropped to 1.48 (95\% Cl: 0.94-2.32) after inverse-probability weighting $(P=0.09)$. No such relations were found with TSH.

Conclusions: Maternal hypothyroxinaemia at the end of the first trimester was associated with reduced performance in an arithmetic test, but not in a language test, in 5-year-old offspring. However, our results should be interpreted carefully because of possible non-response bias.

\section{Introduction}

Thyroid hormones are essential for brain development already in the early embryonic phase. The foetal thyroid hormone production does not begin before the second trimester of pregnancy and, therefore, in early pregnancy the developing brain relies entirely on the supply of maternal thyroid hormone (1). (c) 2015 European Society of Endocrinology Printed in Great Britain
The association between hypothyroidism caused by severe iodine deficiency during pregnancy and neurological cretinism in the offspring has been recognized for almost a century (2). More recently, less severe impairments in thyroid function of pregnant women have also been associated with cognitive impairments in their

Published by Bioscientifica Ltd. 
offspring (3). At age 7-9 years, children of mothers with clinical hypothyroidism at the 17th week of gestation had a lower intelligence quotient (IQ) as well as lower scores on tests of attention and visuomotor performance compared to age-matched controls born to euthyroid mothers (3).

A growing body of evidence indicates that developmental delay even occurs in children whose mothers had thyroxine $\left(\mathrm{T}_{4}\right)$ levels that were slightly lower (but still within the normal range) early in pregnancy $(4,5,6,7,8)$, although some studies were negative $(9,10)$. However, participants in these studies were followed until the age of 3 using developmental tests like the Bayley Scales of Infant Development (version II), which have a poor prognostic value for future cognitive impairments $(11,12)$. Therefore, it is unknown whether these associations persist for life.

Recently, we and others were able to extend these observations to the early school years, when specific cognitive functions are challenged for the first time (13). In a large, community-based sample of mothers and children, we found that a lower maternal free $\mathrm{T}_{4}$ concentration at the end of the first trimester was associated with reduced performance in a simple reaction time task at age 5-6 years (14). Similarly, in the Generation $\mathrm{R}$ study, children born to mothers with a maternal free $\mathrm{T}_{4}$ concentration in the lowest $5 \%$ of distribution in early pregnancy exhibited a 4.3-point reduction in nonverbal IQ at age 6 years (15). However, their verbal IQ was not assessed.

In the present study, we investigated whether maternal free $\mathrm{T}_{4}$ and thyrotropin (TSH) concentrations at the end of the first trimester of pregnancy were associated with scores on arithmetic and language tests, obtained during the national monitoring and evaluation program at schools, at age 5 years.

\section{Subjects and methods}

\section{Population}

This study is part of the Amsterdam Born Children and Their Development (ABCD) study, which follows a community-based, multi-ethnic cohort of women and children. The details of the cohort retrieval are described elsewhere (16). In short, between January 2003 and March 2004, 12373 pregnant women were invited to participate at their first prenatal visit to an obstetric caregiver. Of the total, 8266 enrolled by returning the pregnancy questionnaire. From this questionnaire, age, ethnicity, BMI, years of education, health status and medication use were retrieved. BMI was based on the self-reported height and weight before pregnancy. Information on hypertension and diabetes mellitus was available from the questionnaire and completed by probabilistic medical record linkage with the Netherlands Perinatal Registry (17). Maternal depressive symptoms during pregnancy were also measured by self-report in the pregnancy questionnaire, by using the Center for Epidemiologic Studies Depression scale (CES-D) $(18,19)$. The CES-D is designed to determine depressive symptomatology in the week previous to the acquisition of the questionnaire and does not aim to identify chronic or clinical depression (18). In total, 4389 women gave approval for the biomarker study, which involved analysis of free $\mathrm{T}_{4}$, TSH and anti-thyroid peroxidase (TPO) antibodies.

When the children turned 5 years, mothers who had initially given permission for follow-up and whose addresses could be retrieved $(n=6161)$ were asked for permission to obtain information, including school test results, from their children's school. Permission was granted by 3867 mothers.

Children with congenital malformations were excluded, as were children of women who used thyroid inhibitors during their pregnancies $(n=176)$. School test results were available for 2141 children. Levels of maternal free $\mathrm{T}_{4}$ and TSH were available for 1196 and 1185 of them respectively. The flow chart of the study sample is shown in Fig. 1.

The study was approved by the medical ethical committees of the participating hospitals and the Registration Committee of the Health Municipality of Amsterdam. All women gave written informed consent for themselves and their children.

\section{Laboratory analysis}

TSH and free $\mathrm{T}_{4}$ were measured using access immunoanalyser of Beckman Coultier, Inc. (Fullerton, CA, USA). For men and non-pregnant women, the reference range for TSH was $0.34-5.60 \mathrm{mU} / \mathrm{l}$ and for free $\mathrm{T}_{4}$ it was $7.5-21.1 \mathrm{pmol} / \mathrm{l}$. The sensitivity of the TSH assay was $0.1 \mathrm{mU} / 1$ and the interassay coefficient of variation was $5.0 \%$. The detection limit of the free $\mathrm{T}_{4}$ assay was $1.9 \mathrm{pmol} / \mathrm{l}$ and the interassay coefficient of variation ranged between 3.1 and 5.0\%. Antibodies against TPO were investigated using ELISA ELIZEN TG Ab (E-CK-96, Zentech, Angleur, Belgium). The interassay coefficient of variation was $13.4 \%$. An anti-TPO concentration $>80 \mathrm{kU} / \mathrm{l}$ was considered positive. 


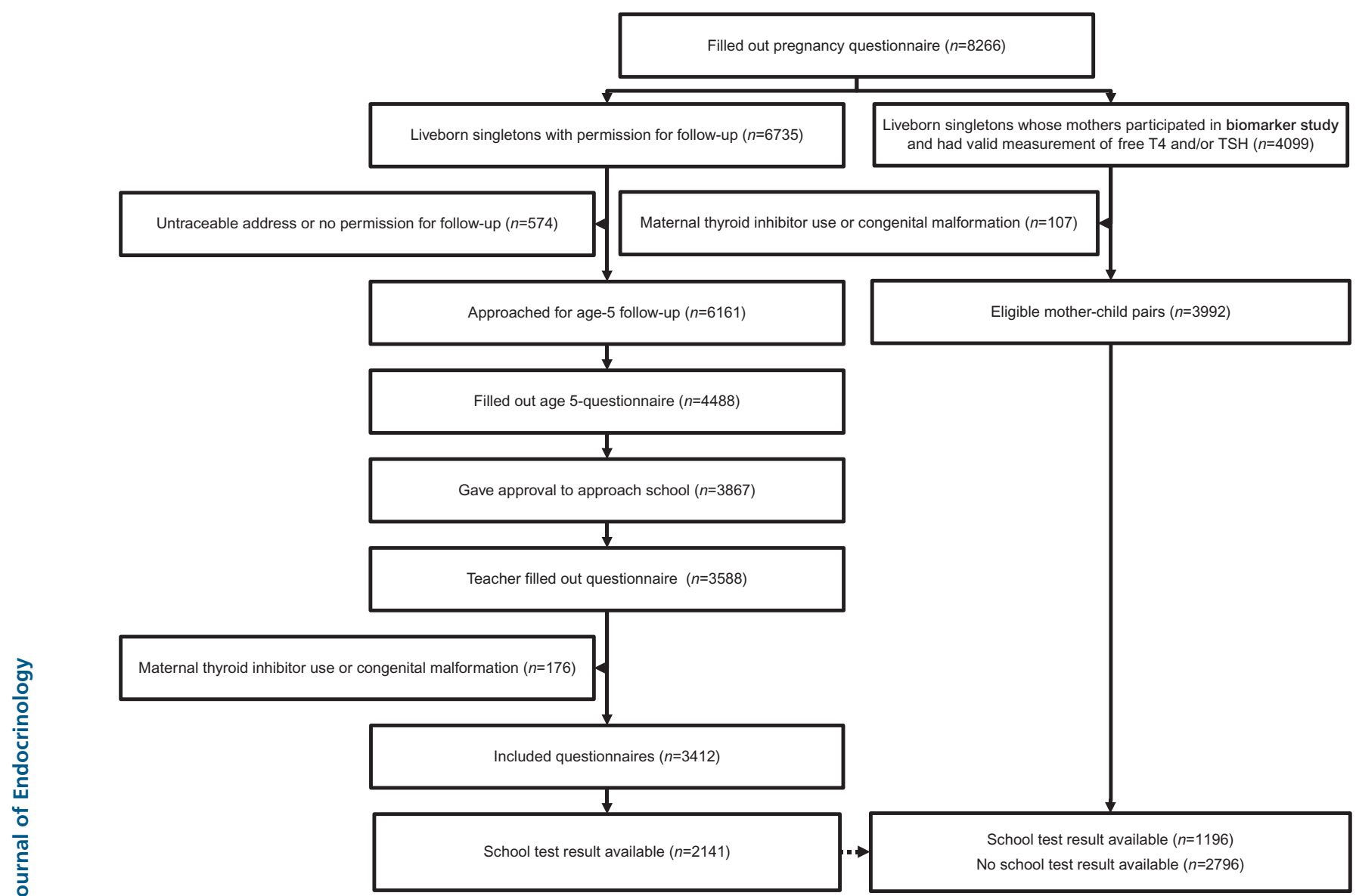

Figure 1

Composition of study sample.

\section{School performance}

School performance was based on Central Institute for Test Development (CITO) test results, which are part of the national monitoring and evaluation system for primary school children (aged 4-12 years) in the Netherlands. For 4- to 6-year-old children, CITO offers arithmetic and language tests. The composition of these tests is listed in Table 1 for grades 1 and 2 separately (20). The number of correct answers is transformed, based on an item response theory-based model, into a skill score depending on the time of testing (halfway or at the end of grade 1 or 2 ). The skill score is subsequently transformed into a rank score, based on normative data. The rank score ranges from $A$ to $E$, in which A represents the highest quarter of test performance and $\mathrm{E}$ the lowest $10 \%$. B, C and D represent the $26-50,51-75$ and $76-90 \%$ of distribution in test scores, respectively.
These tests were nationally validated among 1200 children from selected schools, so that all socio-economic classes were equally represented. The skill score increased from $36.94 \pm 8.72$ halfway grade 1 to $58.24 \pm 11.08$ at the end of grade 2 for the arithmetic test and from $56.47 \pm 8.72$ to $73.34 \pm 9.28$ for the language test (20). The correlation between skill scores was always $>0.70$ (20).

For our study, only the children's most recent rank scores available were provided by the schools.

\section{Statistical analysis}

Maternal free $T_{4}$ was standardized for the postmenstrual day at which blood sampling occurred, because it declined with $0.028 \mathrm{pmol} / \mathrm{l}$ per gestational day $(P<0.001)$. In ten subjects, the gestational day at which their mothers were sampled was not known, and therefore their data were excluded from analyses involving free $\mathrm{T}_{4}$. 
Table 1 Composition of the CITO arithmetic and language tests (20).

\begin{tabular}{|c|c|c|c|}
\hline Grade 1 & $\begin{array}{l}\text { Number of } \\
\text { questions }\end{array}$ & Grade 2 & $\begin{array}{l}\text { Number of } \\
\text { questions }\end{array}$ \\
\hline \multicolumn{4}{|l|}{ Arithmetic test } \\
\hline Colors & 6 & Shapes & 6 \\
\hline Shapes & 6 & Classifying & 6 \\
\hline Classifying & 6 & Sequencing & 12 \\
\hline Size & 6 & Comparing & 6 \\
\hline Sequencing & 6 & Counting & 6 \\
\hline Comparing & 6 & Numbers & 6 \\
\hline Counting & 6 & & \\
\hline Total & 42 & Total & 42 \\
\hline \multicolumn{4}{|l|}{ Language test } \\
\hline Passive vocabulary & 32 & Passive vocabulary & 16 \\
\hline \multirow[t]{5}{*}{ Accurate listening } & 16 & Accurate listening & 8 \\
\hline & & Sound and rhyme & 8 \\
\hline & & $\begin{array}{l}\text { Recognition of first } \\
\text { and last word }\end{array}$ & 8 \\
\hline & & Orientation in writing & 8 \\
\hline & & Auricular synthesis & 8 \\
\hline Total & 48 & Total & 56 \\
\hline
\end{tabular}

Multivariable logistic regression analysis was used to test the effects of thyroid hormones across the entire range on poor or subnormal school performance (i.e., a rank score below $\mathrm{C}$ or $\mathrm{B}$ respectively). Analyses were also conducted using cut-offs for free $\mathrm{T}_{4}$ and $\mathrm{TSH}$. In line with previous studies, and taking into account the limited number of children with adverse test outcomes, hypothyroxinaemia was defined as a free $\mathrm{T}_{4}$ level $<10$ th percentile of distribution ( $<8.06 \mathrm{pmol} / \mathrm{l}$ in our sample), and hyperthyrotropinaemia as a TSH level $>90$ th percentile $(>2.30 \mathrm{mU} / \mathrm{l})(5,8,14)$.

Confounders were selected a priori, based on the literature $(3,8,14,15)$, and were included in the regression equation if association $(P<0.1)$ with both predictor and outcome was found. Among the variables listed in Table 2, this was the case for maternal education, ethnicity, BMI and depressive symptomatology. Maternal age, hypertension, diabetes, smoking, timing of blood sampling, TPO antibody positivity, child gender, gestational age and birth weight were not associated with predictor and outcome and were therefore not included in the regression equation. Analyses were repeated after exclusion of children who were born very preterm (i.e., $<32$ weeks of gestation) and/or with a very low birth weight (i.e., $<1500 \mathrm{~g}$ ), because neonatal $\mathrm{T}_{4}$ levels tend to be low in these groups $(21,22)$.

Inverse-probability weighting was used to estimate the impact of possible non-response bias. First, the probability of participating in this study was predicted for all children in the cohort using a logistic regression with the characteristics listed in Table 2 as predictors and participation as the outcome. The inverses of these predicted probabilities were then used as sampling weights in Stata 12 (StataCorp, College Station, TX, USA) to perform a weighted logistic regression on the data of the participants with school performance as outcome and maternal thyroid function parameters as predictors.

\section{Results \\ Maternal and birth characteristics}

The characteristics of participants and non-participants are presented in Table 2. Maternal characteristics associated with non-response were younger age, fewer years of education, non-western ethnicity, depressive symptomatology and later blood sampling. Children who did not participate were born slightly earlier and with a lower birth weight.

Maternal hypothyroxinaemia was associated with a higher BMI, fewer years of education, non-western ethnicity, smoking during pregnancy, hypertension and depressive symptomatology. Furthermore, maternal hypothyroxinaemia was associated with a higher TSH level and with anti-TPO antibody positivity.

\section{School test results}

Table 3 shows the school performance results of the children included in our sample. There were 1016 children who had scores available for both tests, 71 for the arithmetic test only, and 109 for the language test only. The tests were administered at an age of $4.8 \pm 0.3$ years. Compared to the norm population, for both tests there was an overrepresentation of A scores and an underrepresentation of $\mathrm{C}, \mathrm{D}$ and $\mathrm{E}$ scores. The correlation between the arithmetic and language test rank scores in our sample was 0.60 (Spearman $\rho, P<0.001$ ). The distribution in rank scores differed between hypothyroxinaemic and non-hypothyroxinaemic groups, with hypothyroxinaemia being associated with lower rank scores in both tests.

\section{Associations}

Table 4 presents associations between maternal thyroid function parameters and arithmetic performance. Maternal free $\mathrm{T}_{4}$ across the entire range was inversely associated with the odds of subnormal arithmetic performance, and this relation became non-significant after 
Table 2 Maternal and child characteristics. Values represent mean \pm s.D., median (interquartile range) or $n$ (\%). Continuous variable were compared with the unpaired $t$-test or the Mann-Whitney $U$ test where appropriate. Ordinal variables were compared using the $\chi^{2}$ test or Fisher's exact test where appropriate.

\begin{tabular}{|c|c|c|c|c|c|c|}
\hline \multirow[b]{2}{*}{ Characteristic } & \multicolumn{4}{|c|}{ Participants } & \multicolumn{2}{|c|}{ Non-participants } \\
\hline & Entire sample & Hypothyroxinaemic & $\begin{array}{l}\text { Non- } \\
\text { hypothyroxinaemic }\end{array}$ & $P$ value $^{a}$ & Non-participants & $P$ value $^{\mathrm{b}}$ \\
\hline$n$ & 1196 & $118^{c}$ & $1068^{c}$ & - & 2796 & - \\
\hline \multicolumn{7}{|l|}{ Maternal } \\
\hline Age (years) & $31.6 \pm 4.4$ & $31.9 \pm 4.7$ & $31.7 \pm 4.4$ & 0.43 & $30.7 \pm 5.0$ & $<0.001$ \\
\hline Non-western ethnicity (\%) & $228(19.1 \%)$ & $33(28.0 \%)$ & $195(18.3 \%)$ & 0.01 & $799(28.6 \%)$ & $<0.001$ \\
\hline Years of education (years) & $9.7 \pm 3.7$ & $8.7 \pm 3.8$ & $9.9 \pm 3.7$ & 0.001 & $9.0 \pm 3.9$ & $<0.001$ \\
\hline Pre-pregnancy BMI $\left(\mathrm{kg} / \mathrm{m}^{2}\right)$ & $23.0 \pm 3.8$ & $24.5 \pm 4.4$ & $22.8 \pm 3.7$ & $<0.001$ & $22.9 \pm 3.8$ & 0.47 \\
\hline \multicolumn{7}{|l|}{ Hypertension (\%) } \\
\hline No & $1040(87.0 \%)$ & $89(75.4 \%)$ & $942(88.2 \%)$ & $<0.001$ & $2480(88.7 \%)$ & 0.24 \\
\hline Gestational & $106(8.9 \%)$ & $16(13.6 \%)$ & $90(8.4 \%)$ & & $224(8.0 \%)$ & \\
\hline Pre-existent & $50(4.2 \%)$ & $11(13.0 \%)$ & $36(3.4 \%)$ & & $92(3.3 \%)$ & \\
\hline $\begin{array}{l}\text { Gestational or pre-existent } \\
\text { diabetes }(\%)\end{array}$ & $8(0.7 \%)$ & $2(1.7 \%)$ & $6(0.6 \%)$ & 0.19 & $24(0.9 \%)$ & 0.54 \\
\hline Smoking $(\%)$ & $71(6.1 \%)$ & $14(11.1 \%)$ & $57(5.5 \%)$ & 0.01 & $204(7.5 \%)$ & 0.12 \\
\hline Depressive symptomatology (\%) & $289(24.3 \%)$ & $42(35.9 \%)$ & $246(23.2 \%)$ & 0.002 & $810(29.3 \%)$ & 0.001 \\
\hline $\begin{array}{l}\text { Gestational age at blood } \\
\text { sampling (weeks) }\end{array}$ & $12.9(11.9-14.3)$ & $13.0(12.1-14.1)$ & $12.9(11.9-14.3)$ & 0.26 & $13.0(11.9-14.7)$ & 0.02 \\
\hline Free $\mathrm{T}_{4}(\mathrm{pmol} / \mathrm{l})^{\mathrm{d}}$ & $9.6 \pm 1.4$ & $7.6 \pm 0.6$ & $9.9 \pm 1.2$ & $<0.001$ & $9.7 \pm 1.7$ & 0.31 \\
\hline TSH (mU/l) & $1.2(0.8-1.6)$ & $1.5(1.0-2.2)$ & $1.1(0.8-1.6)$ & $<0.001$ & $1.2(0.8-1.7)$ & 0.87 \\
\hline Anti-TPO positivity (\%) & $85(7.1 \%)$ & $18(15.3 \%)$ & $66(6.2 \%)$ & $<0.001$ & $158(5.7 \%)$ & 0.08 \\
\hline \multicolumn{7}{|l|}{ Child } \\
\hline Male sex $(\%)$ & $567(47.4 \%)$ & $60(50.8 \%)$ & $503(47.1 \%)$ & 0.44 & $1371(49.1 \%)$ & 0.34 \\
\hline Gestational age (week) & $39.5 \pm 1.7$ & $39.3 \pm 1.9$ & $39.6 \pm 1.6$ & 0.05 & $39.4 \pm 1.9$ & 0.02 \\
\hline Birth weight $(\mathrm{g})$ & $3490 \pm 543$ & $3536 \pm 652$ & $3489 \pm 522$ & 0.36 & $3440 \pm 582$ & 0.01 \\
\hline
\end{tabular}

${ }^{a}$ Between hypothyroxinaemic and non-hypothyroxinaemic groups.

between participants and non-participants.

In ten cases the gestational age at which blood was sampled was not known.

dStandardized value.

adjustment. Maternal hypothyroxinaemia was associated with an increased odds of subnormal arithmetic performance, and the relation persisted after adjustment. It was also associated with increased odds of poor arithmetic performance, though statistical significance was lost after adjustment. No such relations were found with TSH.

Associations between maternal thyroid function parameters and language performance are displayed in Table 5. Maternal hypothyroxinaemia was associated with increased odds of poor language performance and maternal hyperthyrotropinaemia with decreased odds of subnormal language performance in crude analyses. However, statistical significance was lost after adjustment. The relations found did not change after exclusion of children born very preterm or with a very low birth weight (data not shown).

Table 6 presents the results of inverse-probabilityweighted analyses. The association between maternal hypothyroxinaemia and suboptimal arithmetic performance became weaker and, for the adjusted model, lost statistical significance. The estimated odds ratios were
1.76 (95\% CI: $1.16-2.67 ; P=0.007)$ for the crude model and 1.48 (95\% (95\% CI: 0.94-2.32; $P=0.09)$ for the adjusted model.

\section{Discussion}

The main conclusion from our study is that a free $\mathrm{T}_{4}$ concentration in the lowest $10 \%$ of distribution in women at the end of the first trimester of pregnancy was associated with a 1.61 times higher odds of a subnormal (i.e., in the lowest $50 \%$ of distribution of the norm population) score on an arithmetic test in their children at age 5. However, caution must be exercised in the interpretation of these findings when considering the results of inverse-probability-weighted analyses where the estimate for the odds ratio dropped to 1.48 and was no longer statistically significant. Although a test score in the subnormal range cannot be considered problematic, in our sample, only $30 \%$ of children had a test score below the 50 th percentile of the norm population. Therefore, we believe that the associations found could be potentially relevant. 
Table 3 CITO test results.

\begin{tabular}{|c|c|c|c|}
\hline Rank score & Entire sample & $\begin{array}{c}\text { Hypothyroxi- } \\
\text { naemic }\end{array}$ & $\begin{array}{l}\text { Non-hypothy- } \\
\text { roxinaemic }\end{array}$ \\
\hline$n$ & 1196 & 118 & 1068 \\
\hline \multicolumn{4}{|l|}{$\begin{array}{l}\text { Arithmetic } \\
\text { test }\end{array}$} \\
\hline Missing & 109 & 7 & 100 \\
\hline A & $466(42.9 \%)$ & $36(32.4 \%)$ & $427(44.1 \%)$ \\
\hline B & $299(27.5 \%)$ & $28(25.2 \%)$ & $270(27.9 \%)$ \\
\hline C & $187(17.2 \%)$ & $25(22.5 \%)$ & $160(16.5 \%)$ \\
\hline D & 79 (7.3\%) & $18(16.2 \%)$ & $60(6.2 \%)$ \\
\hline $\mathrm{E}$ & $56(5.2 \%)$ & $4(3.6 \%)$ & $51(5.3 \%)$ \\
\hline$P$ value ${ }^{a}$ & - & \multicolumn{2}{|c|}{0.001} \\
\hline \multicolumn{4}{|c|}{ Language test } \\
\hline Missing & 71 & 10 & 61 \\
\hline A & $457(40.6 \%)$ & $31(28.7 \%)$ & $422(41.9 \%)$ \\
\hline B & $313(27.8 \%)$ & $36(33.3 \%)$ & $274(27.2 \%)$ \\
\hline C & $194(17.2 \%)$ & $18(16.7 \%)$ & $174(17.3 \%)$ \\
\hline D & $86(7.6 \%)$ & $11(10.2 \%)$ & $75(7.4 \%)$ \\
\hline $\mathrm{E}$ & $75(6.7 \%)$ & $12(11.1 \%)$ & $62(6.2 \%)$ \\
\hline$P$ value ${ }^{a}$ & - & \multicolumn{2}{|c|}{0.04} \\
\hline
\end{tabular}

Previous studies found that a lower maternal free $T_{4}$ concentration during early pregnancy was associated with parent-reported language delay and a reduced score on the Mental Development Index of the Bayley Scales of Infant Development (version II) in offspring until the age of 3 $(4,5,6,7,8)$. The Mental Developmental Index of the Bayley test (version II) is a poor predictor of future cognitive impairments (11), even in term-born children (12). Recently, it was found among children in their early school years that those born to mothers who were hypothyroxinaemic early in their pregnancies exhibited several neurodevelopmental deficits, such as slower and less consistent reaction times (14) and a reduction in nonverbal IQ (15). The current data suggest that arithmetic performance obtained during a school test at age 5 may also be reduced after exposure to maternal hypothyroxinaemia at the end of the first trimester.

The current study has several strengths and limitations. The major strengths of our study are the retrieval of a community-based sample of women and children (16) and the use of a school performance estimate that is validated and implemented in the national school surveillance program (20).

A limitation of our study is the substantial number of children that is lost to follow-up, which is almost inevitable for long-term follow-up studies. Therefore, the question arises as to which extent our findings could be biased by selective response. Compared to the norm population, there was an overrepresentation of A scores and an underrepresentation of C, D and E scores for both tests in our sample. Furthermore, our non-response analysis indicated that participants and non-participants differed in a number of characteristics. To estimate the impact of possible non-response bias, we conducted inverse-probability weighted analyses. All associations became weaker and statistical significance was lost for some.

Although crude analyses yielded similar results for both tests, the association between maternal hypothyroxinaemia and subnormal arithmetic performance persisted, although it became weaker, while the relation with poor language test score disappeared after statistical correction. In comparison to task performance, language development of young children is probably more dependent on family factors such as socioeconomic status and maternal responsiveness $(23,24)$. If maternal hypothyroxinaemia is associated with socio economic status, or its indicators

Table 4 Associations between maternal thyroid function parameters and performance on the CITO arithmetic test.

\begin{tabular}{|c|c|c|c|c|c|c|c|c|c|}
\hline \multirow[b]{3}{*}{ Predictor } & \multirow[b]{3}{*}{$\boldsymbol{n}$} & \multicolumn{4}{|c|}{ Poor school performance } & \multicolumn{4}{|c|}{ Subnormal school performance } \\
\hline & & \multirow[b]{2}{*}{ OR } & \multicolumn{2}{|c|}{$95 \% \mathrm{Cl}$} & \multirow[b]{2}{*}{$P$ value } & \multirow[b]{2}{*}{ OR } & \multicolumn{2}{|c|}{$95 \% \mathrm{Cl}$} & \multirow[b]{2}{*}{$P$ value } \\
\hline & & & Lower & Upper & & & Lower & Upper & \\
\hline \multicolumn{10}{|l|}{ Crude analyses } \\
\hline TSH, continuous (mU/l) & 1077 & 0.85 & 0.69 & 1.06 & 0.16 & 0.92 & 0.81 & 1.04 & 0.20 \\
\hline Hyperthyrotropinaemia & 1077 & 0.78 & 0.41 & 1.50 & 0.46 & 1.01 & 0.65 & 1.56 & 0.98 \\
\hline Free $\mathrm{T}_{4}{ }^{a}$, continuous (pmol/l) & 1079 & 0.88 & 0.77 & 1.02 & 0.08 & 0.89 & 0.81 & 0.98 & 0.03 \\
\hline Hypothyroxinaemia & 1079 & 1.91 & 1.15 & 3.17 & 0.01 & 1.89 & 1.26 & 2.82 & 0.002 \\
\hline \multicolumn{10}{|l|}{ Adjusted analyses ${ }^{b}$} \\
\hline TSH, continuous (mU/l) & 1065 & 0.94 & 0.77 & 1.14 & 0.51 & 0.96 & 0.85 & 1.07 & 0.42 \\
\hline Hyperthyrotropinaemia & 1065 & 0.91 & 0.45 & 1.85 & 0.79 & 1.12 & 0.74 & 1.86 & 0.50 \\
\hline Free $\mathrm{T}_{4}{ }^{a}$, continuous (pmol/l) & 1067 & 0.92 & 0.80 & 1.07 & 0.27 & 0.92 & 0.83 & 1.02 & 0.10 \\
\hline Hypothyroxinaemia & 1067 & 1.54 & 0.89 & 2.66 & 0.13 & 1.61 & 1.05 & 2.47 & 0.03 \\
\hline
\end{tabular}


Table 5 Associations between maternal thyroid function parameters and performance on the CITO language test.

\begin{tabular}{|c|c|c|c|c|c|c|c|c|c|}
\hline \multirow[b]{3}{*}{ Predictor } & \multirow[b]{3}{*}{$n$} & \multicolumn{4}{|c|}{ Poor school performance } & \multicolumn{4}{|c|}{ Subnormal school performance } \\
\hline & & \multirow[b]{2}{*}{ OR } & \multicolumn{2}{|c|}{$95 \% \mathrm{Cl}$} & \multirow[b]{2}{*}{$P$ value } & \multirow[b]{2}{*}{ OR } & \multicolumn{2}{|c|}{$95 \% \mathrm{Cl}$} & \multirow[b]{2}{*}{$P$ value } \\
\hline & & & Lower & Upper & & & Lower & Upper & \\
\hline \multicolumn{10}{|l|}{ Crude analyses } \\
\hline TSH, continuous (mU/l) & 1115 & 0.97 & 0.85 & 1.10 & 0.59 & 0.90 & 0.79 & 1.03 & 0.11 \\
\hline Hyperthyrotropinaemia & 1115 & 0.77 & 0.42 & 1.42 & 0.41 & 0.60 & 0.38 & 0.96 & 0.03 \\
\hline Free $\mathrm{T}_{4}{ }^{\mathrm{a}}$, continuous (pmol/l) & 1115 & 0.95 & 0.84 & 1.08 & 0.45 & 0.98 & 0.90 & 1.08 & 0.73 \\
\hline Hypothyroxinaemia & 1115 & 1.72 & 1.05 & 2.82 & 0.03 & 1.36 & 0.91 & 2.07 & 0.13 \\
\hline \multicolumn{10}{|l|}{ Adjusted analyses ${ }^{\mathrm{b}}$} \\
\hline $\mathrm{TSH}$, continuous (mU/l) & 1104 & 1.03 & 0.95 & 1.11 & 0.54 & 0.96 & 0.86 & 1.07 & 0.43 \\
\hline Hyperthyrotropinaemia & 1104 & 1.06 & 0.55 & 2.03 & 0.86 & 0.68 & 0.41 & 1.11 & 0.12 \\
\hline Free $\mathrm{T}_{4}{ }^{a}$, continuous (pmol/l) & 1104 & 1.02 & 0.90 & 1.16 & 0.77 & 1.02 & 0.93 & 1.13 & 0.66 \\
\hline Hypothyroxinaemia & 1104 & 1.23 & 0.71 & 2.13 & 0.46 & 1.09 & 0.70 & 1.70 & 0.71 \\
\hline
\end{tabular}

aStandardized value.

${ }^{\mathrm{b}}$ Adjusted for maternal education, ethnicity, BMI and depressive symptomatology.

(Table 2), and this in turn with language test score, it would explain why the relation between hypothyroxinaemia and poor language test score disappeared after statistical correction for the family background. Another explanation for the lack of association with language test score is that there is evidence for a spatiotemporal effect of free $\mathrm{T}_{4}$ on early brain development (25). According to the constructs of Zoeller and Rovet, language and verbal development are more dependent on the early-postnatal, rather than on the prenatal, supply of free $T_{4}(25)$, although in the Generation R study, correlations between first-trimester maternal hypothyroxinaemia $<5$ th percentile and expressive language delay in offspring at ages 18 and 30 months were demonstrated (8).

Our present results show that previous observations in the $\mathrm{ABCD}$ study linking lower free $\mathrm{T}_{4}$ levels in women

Table 6 Inverse-probability weighted analyses.

\begin{tabular}{|c|c|c|c|c|c|c|c|c|c|}
\hline \multirow[b]{3}{*}{ Predictor } & \multirow[b]{3}{*}{ n } & \multicolumn{4}{|c|}{ Poor school performance } & \multicolumn{4}{|c|}{ Subnormal school performance } \\
\hline & & \multirow{2}{*}{$\begin{array}{c}\text { Estimated } \\
\text { OR }\end{array}$} & \multicolumn{2}{|c|}{$95 \% \mathrm{Cl}$} & \multirow[b]{2}{*}{$P$ value } & \multirow{2}{*}{$\begin{array}{c}\text { Estimated } \\
\text { OR }\end{array}$} & \multicolumn{2}{|c|}{$95 \% \mathrm{Cl}$} & \multirow[b]{2}{*}{$P$ value } \\
\hline & & & Lower & Upper & & & Lower & Upper & \\
\hline \multicolumn{10}{|l|}{ Arithmetics test } \\
\hline \multicolumn{10}{|l|}{ Crude analyses } \\
\hline TSH, continuous (mU/l) & 1055 & 0.83 & 0.67 & 1.02 & 0.09 & 0.91 & 0.81 & 1.02 & 0.11 \\
\hline Hyperthyrotropinaemia & 1055 & 0.78 & 0.39 & 1.56 & 0.48 & 1.05 & 0.67 & 1.65 & 0.83 \\
\hline Free $\mathrm{T}_{4}{ }^{\mathrm{a}}$, continuous (pmol/l) & 1055 & 0.92 & 0.77 & 1.10 & 0.35 & 0.93 & 0.83 & 1.04 & 0.18 \\
\hline Hypothyroxinaemia & 1055 & 1.83 & 1.09 & 3.09 & 0.02 & 1.76 & 1.16 & 2.67 & 0.007 \\
\hline \multicolumn{10}{|l|}{ Adjusted analyses ${ }^{b}$} \\
\hline TSH, continuous (mU/l) & 1055 & 0.91 & 0.76 & 1.09 & 0.30 & 0.95 & 0.86 & 1.04 & 0.25 \\
\hline Hyperthyrotropinaemia & 1055 & 0.98 & 0.47 & 2.01 & 0.98 & 1.26 & 0.81 & 1.96 & 0.31 \\
\hline Free $\mathrm{T}_{4}{ }^{\mathrm{a}}$, continuous (pmol/l) & 1055 & 0.95 & 0.81 & 1.12 & 0.52 & 0.95 & 0.86 & 1.06 & 0.35 \\
\hline Hypothyroxinaemia & 1055 & 1.44 & 0.81 & 2.57 & 0.22 & 1.48 & 0.94 & 2.32 & 0.09 \\
\hline \multicolumn{10}{|l|}{ Language test } \\
\hline \multicolumn{10}{|l|}{ Crude analyses } \\
\hline TSH, continuous (mU/l) & 1094 & 0.96 & 0.83 & 1.10 & 0.54 & 0.88 & 0.74 & 1.04 & 0.13 \\
\hline Hyperthyrotropinaemia & 1094 & 0.80 & 0.43 & 1.49 & 0.49 & 0.61 & 0.38 & 1.00 & 0.05 \\
\hline Free $\mathrm{T}_{4}{ }^{a}$, continuous (pmol/l) & 1094 & 0.99 & 0.86 & 1.15 & 0.94 & 1.01 & 0.92 & 1.11 & 0.84 \\
\hline Hypothyroxinaemia & 1094 & 1.66 & 0.99 & 2.75 & 0.05 & 1.41 & 0.93 & 2.15 & 0.11 \\
\hline \multicolumn{10}{|l|}{ Adjusted analyses $^{\mathrm{b}}$} \\
\hline TSH, continuous (mU/I) & 1094 & 1.03 & 0.97 & 1.09 & 0.39 & 0.95 & 0.84 & 1.07 & 0.38 \\
\hline Hyperthyrotropinaemia & 1094 & 1.09 & 0.57 & 2.10 & 0.79 & 0.72 & 0.44 & 1.17 & 0.18 \\
\hline Free $\mathrm{T}_{4}{ }^{\mathrm{a}}$, continuous (pmol/l) & 1094 & 1.05 & 0.92 & 1.19 & 0.49 & 1.04 & 0.95 & 1.14 & 0.36 \\
\hline Hypothyroxinaemia & 1094 & 1.20 & 0.70 & 2.10 & 0.50 & 1.12 & 0.72 & 1.76 & 0.59 \\
\hline
\end{tabular}

astandardized value.

${ }^{\mathrm{b}}$ Adjusted for maternal education, ethnicity, BMI and depressive symptomatology. 
early in their pregnancies to slower speed of information processing and lower stability in task performance in their children (14), could possibly be extended with school performance. In adults, these components were strong predictors of performance intelligence (26); thus, of the capacity in dealing with nonverbal, mostly mathematical skills.

It remains questionable whether screening for thyroid function abnormalities during pregnancy is effective. Thus far, only one randomized controlled trial on maternal screening and subsequent treatment for mild thyroid dysfunction in early pregnancy have been conducted (27). Levothyroxine was started, on average, at 13 weeks and 3 days of gestation. At 3 years of age, no difference in IQ score was found between treated and untreated children. However, initiation of levothyroxine might have been too late to improve outcome. An alternative explanation for this negative finding is that assessment at age 3 might have been too early to defect a difference in outcome. IQ testing at age 7-10 years is scheduled for the children who participated in this trial (28).

A potential implication of the current study is that early referral of children whose mothers were hypothyroxinaemic early in their pregnancies for help in mathematics might be considered. However, because it is unknown whether the associations found persist, it is too early to make such a recommendation. Moreover, thyroid function tests are not part of the routine work-up in early pregnancy.

In conclusion, in this community-based sample, we found that a maternal free $\mathrm{T}_{4}$ concentration in the lowest $10 \%$ of distribution at the end of the first trimester of pregnancy was associated with an increased odds of subnormal arithmetic performance during a school test in offspring at the age of 5 . However, our results should be interpreted carefully, because of possible non-response bias.

\section{Declaration of interest}

The authors declare that there is no conflict of interest that could be perceived as prejudicing the impartiality of the research reported.

\section{Funding}

This work was supported by the Netherlands Organization for Health Research and Development (grant number 21000076).

\section{Author contribution statement}

A-M Noten was involved in the data collection, analysed the data, drafted the initial manuscript and approved the final manuscript as submitted.
E M Loomans was involved in the data collection, critically reviewed the manuscript and approved the final manuscript as submitted. T G M Vrijkotte and $\mathrm{M}$ van Eijsden conceptualized and designed the study, coordinated and supervised the data collection, critically reviewed the manuscript and approved the final manuscript as submitted. P M van de Ven did the inverse-probability weighted analyses, critically reviewed the manuscript and approved the final manuscript as submitted. A S P van Trotsenburg and J Rotteveel interpreted the data, critically reviewed the manuscript and approved the final manuscript as submitted. M J J Finken supervised the data collection, analysed and interpreted the data, critically reviewed the manuscript and approved the final manuscript as submitted.

\section{References}

1 Morreale de Escobar G, Obregon MJ \& Escobar del Rey F. Maternal thyroid hormones early in pregnancy and brain development. Best Pract Res Clin Endocrinol Metab 200418 225-248. (doi:10.1016/j.beem.2004. 03.012)

2 McCarrison R. The Thyroid Gland in Health and Disease, New York, NY: William Wood \& Company, 1917.

3 Haddow JE, Palomaki GE, Allan WC, Williams JR, Knight GJ, Gagnon J, O'Heir CE, Mitchell ML, Hermos RJ, Waisbren SE, Klein RZ et al. Maternal thyroid deficiency during pregnancy and subsequent neuropsychological development of the child. N Engl J Med 1999341 549-555. (doi:10.1056/NEJM199908193410801)

4 Smit BJ, Kok JH, Vulsma T, Briët JM, Boer K \& Wiersinga WM. Neurologic development of the newborn and young child in relation to maternal thyroid function. Acta Paediatr 200089 291-295. (doi:10.1111/j.1651-2227.2000.tb18424.x)

5 Pop VJ, Kuijpens JL, van Baar AL, Verkerk G, van Son MM, de Vijlder JJ, Vulsma T, Wiersinga WM, Drexhage HA \& Vader HL. Low maternal free thyroxine concentrations during early pregnancy are associated with impaired psychomotor development in infancy. Clin Endocrinol (Oxf) 199950 149-155. (doi:10.1046/j.1365-2265.1999.00639.x)

6 Pop VJ, Brouwers EP, Vader HL, Vulsma T, van Baar AL \& de Vijlder JJ. Maternal hypothyroxinaemia during early pregnancy and subsequent child development: a 3-year follow-up study. Clin Endocrinol (Oxf) 2003 59 282-288. (doi:10.1046/j.1365-2265.2003.01822.x)

7 Li Y, Shan Z, Teng W, Yu X, Li Y, Fan C, Teng X, Guo R, Wang H, Li J et al. Abnormalities of maternal thyroid function during pregnancy affect neuropsychological development of their children at 25-30 months. Clin Endocrinol (Oxf) 201072 825-829. (doi:10.1111/j.13652265.2009.03743.x)

8 Henrichs J, Bongers-Schokking JJ, Schenk JJ, Ghassabian A, Schmidt HG, Visser TJ, Hooijkaas H, de Muinck Keizer-Schrama SM, Hofman A, Jaddoe VV et al. Maternal thyroid function during early pregnancy and cognitive functioning in early childhood: the Generation R study. J Clin Endocrinol Metab 201095 4227-4234. (doi:10.1210/jc.2010-0415)

9 Oken E, Braverman LE, Platek D, Mitchell ML, Lee SL \& Pearce EN. Neonatal thyroxine, maternal thyroid function, and child cognition. J Clin Endocrinol Metab 200994 497-503. (doi:10.1210/jc.2008-0936)

10 Craig WY, Allan WC, Kloza EM, Pulkkinen AJ, Waisbren S, Spratt DI, Palomaki GE, Neveux LM \& Haddow JE. Mid-gestational maternal free thyroxine concentration and offspring neurocognitive development at two years of age. J Clin Endocrinol Metab 201297 E22-E28. (doi:10.1210/ jc.2011-1772)

11 Hack M, Taylor HG, Drotar D, Schluchter M, Cartar L, WilsonCostello D, Klein N, Friedman H, Mercuri-Minich N \& Morrow M. Poor predictive validity of the Bayley Scales of Infant Development for cognitive function of extremely low birth weight children at school age. Pediatrics 2005116 333-341. (doi:10.1542/peds.2005-0173)

12 Roberts G, Anderson PJ, Doyle LW \& Victorian Infant Collaborative Study Group . The stability of the diagnosis of developmental disability 
between ages 2 and 8 in a geographic cohort of very preterm children born in 1997. Arch Dis Child 201095 786-790. (doi:10.1136/adc.2009. 160283)

13 Kalff AC, de Sonneville LM, Hurks PP, Hendriksen JG, Kroes M, Feron FJ, Steyaert J, van Zeben TM, Vles JS \& Jolles J. Speed, speed variability, and accuracy of information processing in 5- to 6-year-old children at risk of ADHD. J Int Neuropsychol Soc 200511 173-183. (doi:10.1017/ S1355617705050216)

14 Finken MJ, van Eijsden M, Loomans EM, Vrijkotte TG \& Rotteveel J. Maternal hypothyroxinemia in early pregnancy predicts reduced performance in reaction time tests in 5- to 6-year-old offspring. J Clin Endocrinol Metab 201398 1417-1426. (doi:10.1210/jc.2012-3389)

15 Ghassabian A, El Marroun H, Peeters RP, Jaddoe VW, Hofman A, Verhulst FC, Tiemeier H \& White T. Downstream effects of maternal hypothyroxinemia in early pregnancy: nonverbal IQ and brain morphology in school-age children. J Clin Endocrinol Metab 201499 2383-2390. (doi:10.1210/jc.2013-4281)

16 Van Eijsden M, Vrijkotte TG, Gemke RJ \& van der Wal MF. Cohort profile: the Amsterdam Born Children and their Development (ABCD) study. Int J Epidemiol 201140 1176-1186. (doi:10.1093/ije/dyq128)

17 Tromp M, van Eijsden M, Ravelli AC \& Bonsel GJ. Anonymous nonresponse analysis in the ABCD cohort study enabled by probabilistic record linkage. Pediatr Perinat Epidemiol 200923 264-272. (doi:10.1111/ j.1365-3016.2009.01030.x)

18 Radloff LS. The CES-D scale: a self-reported depression scale for research in the general population. Appl Psychol Meas 1977 1 385-401. (doi:10.1177/014662167700100306)

19 Goedhart G, Snijders AC, Hesselink AE, van Poppel MN, Bonsel GJ \& Vrijkotte TG. Maternal depressive symptoms in relation to perinatal mortality and morbidity: results from a large multiethnic cohort study. Psychosom Med 201072 769-776. (doi:10.1097/PSY. Ob013e3181ee4a62)

20 Van Kuyk J, Kamphuis F. Verantwoording van de toetsen uit de pakketten Ruimte en Tijd, Taal voor Kleuters en Ordenen. Arnhem: Citogroep, 2001
21 Van Wassenaer AG, Kok JH, Dekker FW \& de Vijlder JJ. Thyroid function in very preterm infants: influences of gestational age and disease. Pediatr Res 199742 604-609. (doi:10.1203/00006450199711000-00009)

22 Frank JE, Faix JE, Hermos RJ, Mullaney DM, Rojan DA, Mitchell ML \& Klein RZ. Thyroid function in very low birth weight infants: effects on neonatal hypothyroidism screening. J Pediatr 1996128 548-554. (doi:10.1016/S0022-3476(96)70368-2)

23 Fernald A, Marchman VA \& Weisleder A. SES differences in language processing skill and vocabulary are evident at 18 months. Dev Sci 2013 16 234-248. (doi:10.1111/desc.12019)

24 Hudson S, Levickis P, Down K, Nicholls R \& Wake M. Maternal responsiveness predicts child language at ages 3 and 4 in a communitybased sample of slow-to-talk toddlers. Int J Lang Commun Disord 201550 136-142. (doi:10.1111/1460-6984.12129)

25 Zoeller RT \& Rovet J. Timing of thyroid hormone action in the developing brain: clinical observations and experimental finding. J Neuroendocrinol 200416 809-818. (doi:10.1111/j.1365-2826.2004. 01243.x)

26 Walhovd KB, Fjell AM, Reinvang I, Lundervold A, Fischl B, Salat D, Quinn BT, Makris N \& Dale AM. Cortical volume and speedof-processing are complementary in prediction of performance intelligence. Neuropsychologia 200543 704-713. (doi:10.1016/ j.neuropsychologia.2004.08.006)

27 Lazarus J, Bestwick JP, Channon S, Paradice R, Maina A, Rees R, Chiusano E, John R, Guaraldo V, George LM et al. Antenatal thyroid screening and childhood cognitive function. N Engl J Med 2012366 493-501. (doi:10.1056/NEJMoa1106104)

28 Hales C, Channon S, Taylor PN, Draman MS, Muller I, Lazarus J, Paradice R, Rees A, Shillabeer D, Gregory JW, Ludgate M et al. The second wave of the Controlled Antenatal Thyroid Screening (CATS II) study: the cognitive assessment protocol. BMC Endocr Disord 201414 95. (doi:10.1186/1472-6823-14-95)

Received 15 April 2015

Revised version received 30 July 2015

Accepted 5 August 2015 